\title{
OXYGENATED GLYCEROL DERIVATIVES AS AN ALTERNATIVE SOURCE OF ENERGY: A REVIEW
}

\author{
Kiany S. B. Cavalcante ${ }^{1,2}$, Mitchell G. S. da Silva ${ }^{1}$, Francisco S. M. Sifrônio ${ }^{1}$, \\ Renata R. S. Valois ${ }^{1}$, Adeilton P. Maciel ${ }^{1}$, Antonio G. Souza ${ }^{2}$, Fernando C. Silva ${ }^{1{ }^{* 1}}$ \\ ${ }^{1}$ Universidade Federal do Maranhão, Dep. de Química, CCET, Campus do Bacanga, São Luis/MA \\ ${ }^{2}$ Universidade Federal da Paraíba, Dep. de Química, CCEN, Campus I, João Pessoa/PB
}

1 e-mail: fcs.ufma@gmail.com

Due to the excessive production of crude glycerol by the Brazilian biodiesel industries, the commercial interest for glycerol derivatives has widely increased. Therefore, several methodologies have been proposed for such purpose, combining the reuse of this abundant raw material with new applications. In such context, this review summarizes a number of works focused on oxygenated glycerol derivatives production, regarding the reactions mechanisms (etherification, acetalization, esterification, and fermentation) and the physicochemical chemical properties and application. Thus, this work aims to contribute to future studies in chemical modification of crude glycerol; hence most of the scientific publications have discussed additives yielded from pure glycerol.

Key words: glycerol, etherification, acetalization, esterification, fermentation

\section{Introduction}

In consequence of the several environmental problems caused by petroleum use, a large number of nations have adopted policy strategies based on renewed energy sources as eolic, photovoltaic and biomass (bioethanol, biodiesel e.g.). The Brazilian Government, through the National Program for Biodiesel Production and Use, made it mandatory the blend of 5\% $(\mathrm{v} / \mathrm{v})$ of biodiesel to the petroleum-based diesel oil, for its commercialization in all territory ${ }^{1}$.

Besides the economic, environmental and social advantages, biodiesel manufacturing results in a large amount of crude glycerol (co-product) with low profitable prices due to its extension in the local market ${ }^{2,3,4}$. Nowadays, crude glycerol has been used as combustive $^{5}$, composite ${ }^{6}$, anaerobic digestive ${ }^{7}$ and nutritious feed for animals (pigs ${ }^{8}$, poultries ${ }^{9}$ and laying hens ${ }^{10}$ ). In general, the crude glycerol properties slightly vary with its manufacture and refine ${ }^{69}$ (Table 1).

However, applying crude glycerol as fuel additive is not technically promising hence its hygroscopic properties and high polarity. In addition, glycerol can polymerizes at high temperatures, causing clogging of internal combustion engines, or partially oxidize into acrolein, being potentially toxic ${ }^{11}$. Conversely, oxy- genated glycerol products (glycerol ethers ${ }^{12}$, glycerol acetals $^{13}$, glycerol esters ${ }^{14}$, and alcohols ${ }^{15}$, e.g.) show noticeable physico-chemical properties for petroleum fuels, improving its combustion and reducing its harmful environmental impact.

Table 1 - Physicochemical characteristics of crude glycerol

\begin{tabular}{|c|c|c|c|}
\hline Test & Method & Unit & Crude glycerol \\
\hline Saybolt viscosity & ASTM D88 & SUS, $100^{\circ} \mathrm{F}$ & 205.5 \\
\hline Specific gravity $60 / 60$ & ASTM D1298 & $60 / 60^{\circ} \mathrm{F}$ & 1.2525 \\
\hline Seta flashpoint & ASTM D3278 & ${ }^{\circ} \mathrm{F}$ & $>250$ \\
\hline Ash & ASTM D3174 & wt $\%$ & 3.805 \\
\hline Carbon & ASTM D5373 & wt \% & 32.8 \\
\hline Hydrogen & ASTM D5373 & wt \% & 8.56 \\
\hline Nitrogen & ASTM D5373 & wt $\%$ & $<0.2$ \\
\hline Oxygen by difference & Calculation & wt $\%$ & 54.55 \\
\hline Total sulfur & ASTM D4239 & wt $\%$ & 0.085 \\
\hline Calorific value & ASTM D5865 & $\mathrm{cal} / \mathrm{g}$ & 3489 \\
\hline$\%$ Water (Karl Fisher) & ASTM D1744 & wt $\%$ & 12.55 \\
\hline Total chlorine & ASTM D808 & $\mu g \cdot g^{-1}$ & 18,150 \\
\hline Mercury & EPA 7471 & $\mu g \cdot g^{-1}$ & $<0.1$ \\
\hline
\end{tabular}

\section{Crude glycerol in Brazil}

According to the National Agency of Petroleum, Natural Gas and Biofuels (ANP), in 2009, the 57 Brazilian power plants has produced approximately 1.6 million $\mathrm{m}^{3}$ biodiesel (Table 2), releasing 178,700 $\mathrm{m}^{3}$ crude glycerol to the internal market ${ }^{16}$. Unfortunately, only a small part of this co-product is promptly commercialized, being the remain portion stored in metal 
tanks under inappropriate conditions.

Table 2 - Production of crude glycerol in Brazil

\begin{tabular}{cccc}
\hline \multirow{2}{*}{ Region } & \multirow{2}{*}{ Number of power plants } & \multicolumn{2}{c}{ Production $\left(\mathbf{m}^{\mathbf{3}}\right.$.year $\left.{ }^{-1}\right)$} \\
\cline { 3 - 4 } & & Biodiesel & Glycerol \\
\hline Midwest & 28 & $640,077.30$ & $71,119.70$ \\
Northeast & 8 & $163,905.14$ & $18,211.68$ \\
North & 6 & $41,821.15$ & $4,646.79$ \\
Southeast & 14 & $284,379,17$ & $31,597.69$ \\
South & 7 & $477,870.56$ & $53,096.73$ \\
\hline Brazil & 63 & $1,608,053.32$ & $178,672.59$ \\
\hline Source:ANP (2010) & & &
\end{tabular}

Contaminants traces originated by the biodiesel synthesis (catalyst, unconverted substances and secondary product) often remains in the crude glycerol phase, influencing on the overall quality of its oxygenated compounds. In the main, the Brazilian biodiesel industries use homogeneous alkaline catalysts (sodium and potassium hydroxide) due to its reasonable low cost and high reactivity ${ }^{4}$. However, the yielded glycerol requires certain purification treatment, such as removal of the applied catalyst and fatty acid salts, being time consuming and expensive processes ${ }^{17,18}$. Day (2008) describes one of these processes by adding inorganic acid (sulfuric, hydrochloric or nitric acid) to glycerol under heating $\left(40-90^{\circ} \mathrm{C}\right)$ and low stirring. The remained water and alcohol traces are then removed under room or reduced pressure, being followed by the precipitated salts ${ }^{19}$. In contrast, industries that apply heterogeneous catalysts (inorganic oxides, modified zeolites etc.) do not have technical restrictions for triacylglycerides saponification or catalyst removal. Contrariwise, they often lead to problems attributed to corrosion of the operation unities ${ }^{2}$.

\section{Glycerol derivatives}

A series of processes are being explored by researchers worldwide for the catalytic conversion of glycerol into potential fuel additives $^{70}$, such as etherification ${ }^{12}$, acetalization ${ }^{13}$, acetylation ${ }^{14}$, and fermentation ${ }^{15}$ of glycerol (Figure 1).

\subsection{Glycerol ethers}

By definition, glycerol ethers contain three oxygen-bound carbons derived from glycerol and $\mathrm{R}_{1}, \mathrm{R}_{2}$ and $\mathrm{R}_{3}$ radicals, being hydrogen atoms or alkylated groups. Preferentially, $\mathrm{R}_{1}$ and $\mathrm{R}_{3}$ are tertiary alkyl groups $\left(\mathrm{C}_{4}-\mathrm{C}_{5}\right)$ or $\mathrm{C}_{1}-\mathrm{C}_{10}$ alkyl groups ${ }^{24,71,72}$.

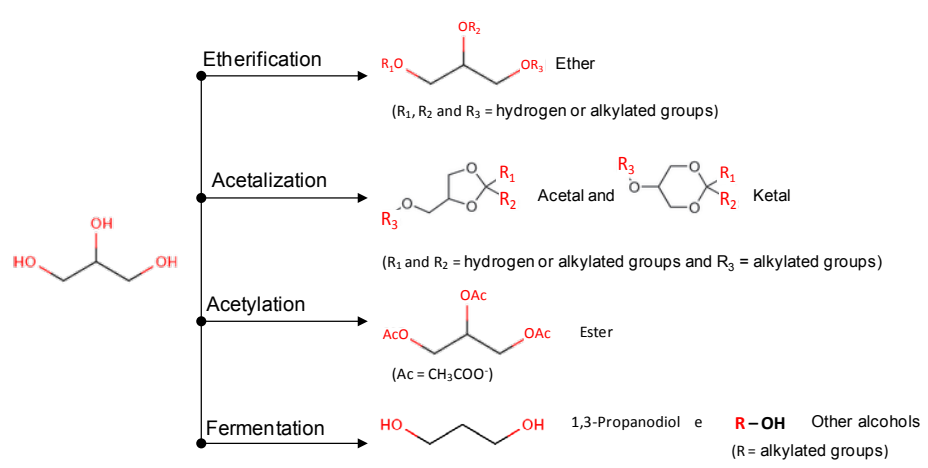

Figure 1 - Conversion of glycerol into oxygenated derivatives.

Glycerol alkyl ethers can be synthesized as described by Williamson ${ }^{21,22}$, though a bimolecular nucleophilic substitution of alkyl halide with alkoxide ions $\left(\mathrm{S}_{\mathrm{N}} 2\right)$. Another acceptable process for ether formation is etherification with an alcohol or olefin in the presence of an acid catalyst ${ }^{23}$. The first commercial patent (US1968033) to define the formation of ether from glycerol used isobutylene reagent and sulfuric acid as catalysis $^{25}$. Aiming to improve the percentage of glycerol ethers, Karinen and Krause $(2003)^{26}$ studied the ideal conditions to expand the selectivity for ethers by modifying the pure glycerol/isobutene molar ratio and temperature. Etherification of glycerol with isobutene results in the substitution of some or all three hydroxyl groups in the glycerol molecule. Thus, up to five ether isomers can be formed depending on the degree of etherification: two mono-substituted ethers (3-tert-butoxy-1,2-propanediol and 2-tert-butoxy-1,3-propanediol), two di-substituted ethers (2,3-di-tert-butoxy-1propanol and 1,3-di-tert-butoxy-2-propanol), and one tri-substituted ether (1,2,3-tri-tert-butoxy-propane), known as glycerol tert-butyl ether (GTBE).

The mono- and di-ethers are the main products when the molar ratio of pure glycerol/isobutene is less than 1:3. However, tri-tert-butyl-glycerol ethers are produced at significant proportions when molar ratios higher than 1:4 are used. In both cases, secondary products of isobutene oligomerization are detected at the beginning of the reaction, which tend to increase when the temperature exceeds $80{ }^{\circ} \mathrm{C}$. This might occur when the activation energy of the oligomerization reaction is higher than that of etherification ${ }^{26}$.

Noureddini et al. (1998) investigated the influence of impurities in glycerol on the etherification reaction. The authors found that the presence of methanol and water residue from the oil transesterification 
process can consume the etherification agent, reacting with isobutylene and forming methyl-tert-butyl ether and tert-butyl alcohol, respectively ${ }^{27}$. Furthermore, the presence of sodium hydroxide deactivates the catalyst and reduces the reaction yield, suggesting that the absence of crude glycerol pretreatment may result in undesired compositions and low conversion rates. In order to minimize these effects, the authors neutralized crude glycerol with Amberlyst-15, preventing the formation of sodium salts. The etherification reaction of crude glycerol pretreated with Amberlyst- 15 showed the same behavior as that of pure glycerol.

Di Serio et al. (2010) proposed a new process in which GTBE were extracted with biodiesel as extraction agent ${ }^{68}$. The final product was a mixture of biodiesel and GTBEs with glycerol content below the required level, which can be used directly as diesel additive. The applied reaction settings were: isobutene/ glycerol molar ratio of $2 ; 1.1 \%(\mathrm{~m} / \mathrm{m})$ Amberlyst-15; temperature of $92{ }^{\circ} \mathrm{C}$; pressure of 15 bar, and reaction time of $480 \mathrm{~min}$. The performance of the process was evaluated by means of preliminary kinetic analysis, demonstrating satisfactory results.

Klepacova et al. $(2003,2006)^{28,29}$ evaluated various catalysts for the etherification of glycerol with isobutene: ion-exchange resins Amberlysts (A) and large-pore zeolites (HY and H-BEA). The conversion results suggested that Amberlysts were the most active catalysts due to the pore size and high degree of crosslinking structure that allows the formation tert-butylether of glycerol. Table 3 summarizes some reaction methodologies (molar ratio of etherification agent/glycerol, temperature, reaction time, and catalyst) used for the conversion of glycerol into ethers using alkenes and alcohols.
Etherification of glycerol produces compounds of lower polarity and viscosity, hence they are often volatile ${ }^{30}$. GTBEs are excellent additives for diesel and biodiesel fuels. Studies have shown that glycerol ethers, i.e., a mixture of 1,3-di-, 1,2-di- and 1,2,3-tri-tert-butyl glycerol, can be incorporated into standard diesel fuel that contain about $30-40 \%$ of aromatic compounds. This addition leads to a significant reduction in the emission of particle matters, hydrocarbons, carbon monoxide, and aldehydes. Also, GTBE can increase the octane number of fuel but, since it is a branched molecule, lowers its cetane number ${ }^{24,31}$. Table 4 shows some of the physicochemical properties of biodiesel and diesel oil containing $400 \mathrm{ppm}$ sulfur and $31 \%$ aromatic compounds, blended with 5\% (v/v) GTBEs, with composition 70:10:2024 and 24:62:14 ${ }^{31}$.

Table 4 - Parameters of diesel-glycerol ether blend

\begin{tabular}{|c|c|c|}
\hline Parameter & Diesel & Diesel blend \\
\hline Solubility & - & Infinite \\
\hline Flashpoint ${ }^{*}$ & $76.6^{\circ} \mathrm{C}$ & $52.2 \%$ \\
\hline Cetane number & 43 & 44 \\
\hline Specific mass, $16^{\circ} \mathrm{C}^{* *}$ & $85.01 \mathrm{~kg} \cdot \mathrm{m}^{-3}$ & $841.9 \mathrm{~kg} \cdot \mathrm{m}^{-3}$ \\
\hline Viscosity** & $4.5 \mathrm{~mm}^{2} \cdot \mathrm{s}^{-1}$ & $2.5 \mathrm{~mm}^{2} \mathrm{~s}^{-1}$ \\
\hline
\end{tabular}

Karas et al. (1994) studied the emission of pollutant gases from a diesel engine. The addition of $5 \%(\mathrm{w} / \mathrm{w})$ GTBEs to certified diesel $(0.25 \%$ sulfur, $43 \%$ aromatic compounds, cetane number: 39) substantially reduces the emission of carbon monoxide and hydrocarbons ${ }^{32}$. The ethers leads to a slightly reduction in particle matter, but it frequently goes with an increase of the $\mathrm{NO}_{\mathrm{x}}$ emission (Figure 2).

Table 3 - Etherification of glycerol

\begin{tabular}{|c|c|c|c|c|c|c|}
\hline \multirow[b]{2}{*}{ Reference } & \multicolumn{6}{|c|}{ Reaction conditions } \\
\hline & Glycerol & $\begin{array}{c}\text { Etherification } \\
\text { agent }\end{array}$ & Molar ratio & Temperature & Time & Catalyst \\
\hline $\begin{array}{l}\text { Klépácoxá et al. } \\
(2003)^{28}\end{array}$ & Pure & Tert-butanol & $1: 4$ & $90^{\circ} \mathrm{C}$ & $3 \mathrm{~h}$ & Amberlyst-15 \\
\hline $\begin{array}{l}\text { Karinen and Krause } \\
(2003)^{26}\end{array}$ & Pure & Isobutylene & $1: 3$ & $80^{\circ} \mathrm{C}$ & $7 \mathrm{~h}$ & Amberlyst-35 \\
\hline $\begin{array}{l}\text { Arredondo et al. } \\
(2007)^{33}\end{array}$ & Pure & Methanol & $1: 2$ & $150^{\circ} \mathrm{C}$ & $4 \mathrm{~h}$ & Amberlyst-15 \\
\hline $\begin{array}{l}\text { Melero et al. } \\
(2008)^{12}\end{array}$ & Pure & Isobutylene & $1: 4$ & $75^{\circ} \mathrm{C}$ & $4 \mathrm{~h}$ & Sulfone silica \\
\hline $\begin{array}{l}\text { Mota et al. } \\
(2009)^{34}\end{array}$ & Pure & Benzyl alcohol & $1: 3$ & $110^{\circ} \mathrm{C}$ & $2 \mathrm{~h}$ & A-35 and zeolite $\beta$ \\
\hline $\begin{array}{l}\text { Pariente et al. } \\
(2009)^{35}\end{array}$ & Pure & Ethanol & $1: 9$ & $\begin{array}{l}160^{\circ} \mathrm{C} \\
200^{\circ} \mathrm{C}\end{array}$ & $6 \mathrm{~h}$ & $\begin{array}{l}\text { A-15 } \\
\text { zeolites, graphite silica }\end{array}$ \\
\hline $\begin{array}{l}\text { Noureddini et al. } \\
(1998)^{27}\end{array}$ & Pretreated & Isobutylene & $1: 3$ & $80^{\circ} \mathrm{C}$ & $2 \mathrm{~h}$ & A-15 \\
\hline
\end{tabular}




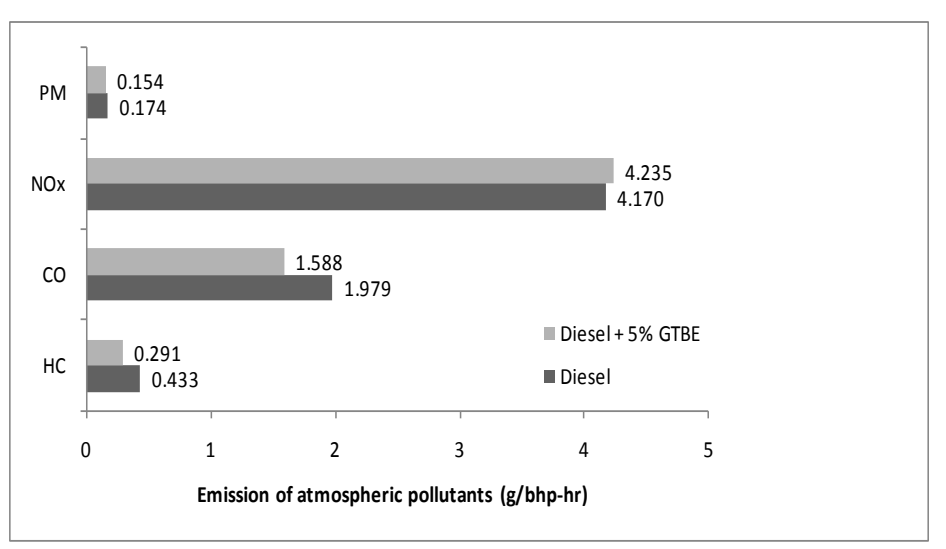

Figure 2 - Emissions from GTBE-fuel blends. PM: particle matter; NOx: nitrogen oxides; CO: carbon monoxide; HC: hydrocarbons. Source: Karas et al. (1994).

\section{Glycerol acetals and ketals}

Acetals and ketals derived from glycerol are obtained by acetalization or transacetalization of glycerol in acid medium with aldehydes and ketones under the action of acid catalysts. Their structure contains $\mathrm{R}_{1}$ and $\mathrm{R}_{2}$ radicals, which generally are hydrogen atoms or a methyl, ethyl or propyl radical, and a methyl or ethyl radical at $\mathrm{R}_{3}{ }^{36}$.

According to Mota et al. (2009) ${ }^{30}$, acetalization of glycerol with ketones almost exclusively results in the formation of a ketal. The ketal contains a five-member ring due to dehydration of the hemiketal and the formation of a tertiary carbocation that is rapidly attacked by the central hydroxyl group, forming the ring. The reaction with aldehydes forms two acetals by dehydration of the hemiacetal through an $\mathrm{S}_{\mathrm{N}} 2$ mechanism.

The first study on the acetalization of pure glycerol was published in 1958 by Piantadosi et al. Table 5 shows some other reaction settings for the formation of glycerol acetals and ketals.
Delfort et al. (2003) adding 1-40\% (v/v) of acetals to diesel oil, observed that the blend solubility was favorable to the separation of compounds during its storage $^{36}$. By means of compression ignition engine test, Nord and Haupt (2005) detected that glycerol acetals/ diesel mixture didn't alter the physicochemical characteristics of fossil fuel (Table 6) and it has lower number of particle materials; however, a high quantity of hydrocarbons and carbon monoxide, 4.9 and $3.8 \%$ respectively, are emitted (Figure 3$)^{37}$. According to the authors, such behavior is attributed to a reduction in cetane number that delays the onset of combustion and reduces the efficiency of the engine. The lower cetane number may also explain the reduced formation of NOx. In contrast, a moderate increase of formaldehyde and acrolein formation was observed, in comparison to acetaldehyde, probably due to incomplete fuel combustion, decomposition and/or oxidation of the acetal.

Table 6 - Parameters of glycerol acetal-diesel blend

\begin{tabular}{|c|c|c|c|}
\hline \multicolumn{2}{|c|}{ Parameter } & Pure diesel & Diesel blend \\
\hline \multirow{2}{*}{\multicolumn{2}{|c|}{$\begin{array}{l}\text { Density }\left(\mathrm{kg} \cdot \mathrm{m}^{-3}\right) \\
\text { Cetane number }\end{array}$}} & 815 & 810 \\
\hline & & 52 & 51 \\
\hline \multirow{2}{*}{ Distillation $\left({ }^{\circ} \mathrm{C}\right)$} & Initial & 180 & 109 \\
\hline & $95 \%$ distilled & 285 & 286 \\
\hline \multicolumn{2}{|c|}{$\begin{array}{l}\text { Flash point }\left({ }^{\circ} \mathrm{C}\right) \\
\text { Cold filter plugging point }\left({ }^{\circ} \mathrm{C}\right) \\
\text { Cloud point }\left({ }^{\circ} \mathrm{C}\right)\end{array}$} & $\begin{array}{c}60 \\
-35 \\
-24\end{array}$ & $\begin{array}{c}32 \\
\text { less than - } 35 \\
-40\end{array}$ \\
\hline \multicolumn{2}{|c|}{ Viscosity, $40^{\circ} \mathrm{C}\left(\mathrm{mm}^{2} \cdot \mathrm{s}^{-1}\right)$} & 1.9 & 1.6 \\
\hline \multicolumn{2}{|c|}{ Corrosivity, copper corrosion } & $1 \mathrm{~A}$ & $1 \mathrm{~A}$ \\
\hline \multicolumn{2}{|l|}{ Lubricity ( $\mu m)$} & 350 & 367 \\
\hline \multicolumn{2}{|c|}{ Thermal value $\left(\mathrm{M} \mathrm{kg}^{-1}\right)$} & 43.1 & 32.0 \\
\hline
\end{tabular}

Table 5 - Acetalization of glycerol

\begin{tabular}{|c|c|c|c|c|c|c|}
\hline \multirow[b]{2}{*}{ Reference } & \multicolumn{6}{|c|}{ Reaction conditions } \\
\hline & Glycerol & $\begin{array}{c}\text { Etherification } \\
\text { agent }\end{array}$ & Molar ratio & Temperature & Time & Catalyst \\
\hline $\begin{array}{l}\text { Piantadosi } \\
(1958)^{41}\end{array}$ & Pure & $\begin{array}{l}\text { Hexadecanal } \\
\text { dimethyl acetal }\end{array}$ & $2: 1$ & $140^{\circ} \mathrm{C}$ & $3 \mathrm{~h}$ & $\begin{array}{l}2.10^{-4} \mathrm{~mol} \% \\
\text { Sulfosalicylic acid }\end{array}$ \\
\hline $\begin{array}{l}\text { Brucbmann et al. } \\
(1999)^{39}\end{array}$ & Pure & Acetone & $1: 4$ & $75^{\circ} \mathrm{C}$ & $9 \mathrm{~h}$ & $\begin{array}{l}0.05 \text { mol \% } \\
\text { p-Toluenesulfonic } \\
\text { acid }\end{array}$ \\
\hline $\begin{array}{l}\text { Delfort et al. } \\
(2003)^{38}\end{array}$ & Pure & n-Butycaldehyde & $1: 1$ & $54^{\circ} \mathrm{C}$ & $7 \mathrm{~h}$ & $\begin{array}{l}2.6 \% \\
\text { Amberlyst-15 }\end{array}$ \\
\hline $\begin{array}{l}\text { Setsul et al. } \\
(2008)^{42}\end{array}$ & Pure & Isobutyraldehyde & $1: 1.2$ & $130^{\circ} \mathrm{C}$ & $3 \mathrm{~h}$ & $\begin{array}{l}0.35 \text { mol } \\
\text { Phosphoric acid }\end{array}$ \\
\hline $\begin{array}{l}\text { Mota } \\
(2009)^{13}\end{array}$ & Pure & $\begin{array}{l}\text { Acetone or } \\
\text { formaldehyde }\end{array}$ & $1: 1.2$ & $70^{\circ} \mathrm{C}$ & $1 \mathrm{~h}$ & Zeolite Beta \\
\hline $\begin{array}{l}\text { Garcia et } \\
(2008)^{40}\end{array}$ al. & Crude & Acetic anhydride & $1: 1.6$ & $\begin{array}{c}\text { Room } \\
\text { temperature }\end{array}$ & $4 \mathrm{~h}$ & - \\
\hline
\end{tabular}




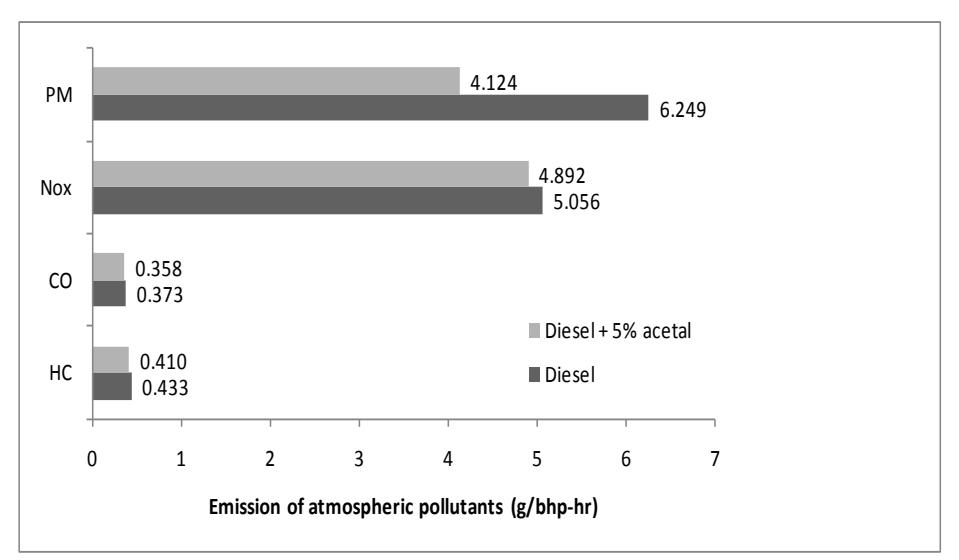

Figure 3 - Emissions of acetal-fuel blends. PM: particle matter; NOx: nitrogen oxides; CO: carbon monoxide; HC: hydrocarbons. Source: Nord and Haupt (2005).

Adding ketals to gasoline, Mota et al. (2010) observed a significant reduction of gum formation in conventional gasoline and ethanol blended gasoline. In contrast, the addition of acetals leads to gum formation. One hypothesis to explain such contradictory behavior is the radical reactions and, consequently, the polymerization of olefins present in gasoline ${ }^{38}$.

The acetal obtained for Bruchmann et al. $(1999)^{39}$, called acetal-1, apparently does not meet the requisite of a low flashpoint and oxidation stability of biodiesel. Garcia et al. $(2008)^{40}$ synthesized a new acetal (2,2-dimethyl-1,3-dioxan-4-yl-methyl acetate) from crude glycerol and acetic anhydride, capable to improve the biodiesel viscosity, flashpoint and oxidation stability.

\section{Glycerol esters}

Triacetin, triacetate ester of glycerol, is a colorless fuel oil, being poorly soluble in water ${ }^{43,44}$. Triacetin can be obtained by means of methyl acetate transesterification or glycerol esterification with acetic acid, also yielding in di-acetin and mono-acetin (intermediate products).
According to Gelosa (2003), conversion efficiency is widely influenced by the reaction mechanism and the equilibrium parameters, being strongly unfavorable to the dehydration of acetic acid ${ }^{45}$ :

$$
\begin{aligned}
& \text { Glycerol }+ \text { acetic acid } \rightleftharpoons \text { monoacetin }+ \text { water }(1) \\
& \text { Monoacetin }+ \text { acetic acid } \rightleftharpoons \text { diacetin }+ \text { water }(2) \\
& \text { Diacetin }+ \text { acetic acid } \rightleftharpoons \text { triacetin }+ \text { water }(3) .
\end{aligned}
$$

The author therefore investigated this organic synthesis catalyzed by acid polymer resin using reactive chromatography, which consists of the simultaneous reaction and separation of the products. The reactor permitted to obtain high conversion rates of glycerol and high purity of the products ${ }^{45}$. Later, Mota et al. $(2008)^{46}$ evaluated the performance of glycerol acetylation using different solid acid catalysts, whom proposed the kinetic mechanism for glycerol into mono-, di- and triacetin. In such work, amberlyst-15 was found to be the most active catalyst, converting $97 \%$, being followed by montmorillonite $\mathrm{K}-10, \mathrm{Nb}_{2} \mathrm{O}_{5}$ and the zeolites HZSM-5 and HUSY. Even expected, the catalyst acidity was not an indicator its catalyst efficiency, with zeolites presenting low conversion and selectivity for di- and triacetin despite its high acidity. Such chemical behavior can be explained by diffusion limitations within the zeolite pores. Other similar reaction as summarized in Table 7 using different types of acid catalysts.

Delgado (2003) produced glycerol triacetate by the reaction of crude glycerol with methyl acetate and potassium hydroxide. When applied as biodiesel additive the glycerol yielded in a high freezing point and

\begin{tabular}{|c|c|c|c|c|c|c|}
\hline \multirow[t]{2}{*}{ Reference } & \multicolumn{6}{|c|}{ Reaction conditions } \\
\hline & Glycerol & $\begin{array}{c}\text { Etherification } \\
\text { agent }\end{array}$ & Molar ratio & Temperature & Time & Catalyst \\
\hline $\begin{array}{l}\text { Gelosa } \\
(2003)^{45}\end{array}$ & Pure & Acetic acid & $1: 4.5$ & $80^{\circ} \mathrm{C}$ & $50 \mathrm{~min}$ & $15 \%$ polymer resin \\
\hline $\begin{array}{l}\text { Mota et al. } \\
(2008)^{46}\end{array}$ & Pure & Acetic acid & $1: 3$ & $110^{\circ} \mathrm{C}$ & $30 \mathrm{~min}$ & $\begin{array}{l}\text { Amberlyst-15, K-10, } \\
\mathrm{Nb}_{2} \mathrm{O} 5, \mathrm{HZSM}-5 \text {, and } \\
\text { HUSY }\end{array}$ \\
\hline $\begin{array}{l}\text { Ferreira et al. } \\
(2009)^{48}\end{array}$ & Pure & Acetic acid & $1: 16$ & $110^{\circ} \mathrm{C}$ & $3 \mathrm{~h}$ & $\begin{array}{l}10 \% \text { NaUSY zeolite } \\
\text { doped with PMo }\end{array}$ \\
\hline $\begin{array}{l}\text { Balaraju et al. } \\
(2010)^{14}\end{array}$ & Pure & Acetic acid & $1: 5$ & $120^{\circ} \mathrm{C}$ & $3 \mathrm{~h}$ & $\begin{array}{l}4 \% \text { Niobia doped with } \\
\text { TPA }\end{array}$ \\
\hline
\end{tabular}
low viscosity of biofuel (Table 8$)^{47}$.

Table 7 - Acetylation of glycerol 
Table 8 - Parameters of glycerol ester-fuel blends

\begin{tabular}{|c|c|c|c|}
\hline \multirow{2}{*}{ Parameter } & \multirow{2}{*}{ Biodiesel } & \multicolumn{2}{|c|}{ Biodiesel blend } \\
\hline & & $5 \%$ Triacetate & $10 \%$ Triacetate \\
\hline Density $^{*}\left(\mathrm{~kg} \cdot \mathrm{m}^{-3}\right)$ & 859.2 & 868.9 & 880.6 \\
\hline Freezing point ${ }^{*}\left({ }^{\circ} \mathrm{C}\right)$ & -7 & -16 & -17 \\
\hline Viscosity $40^{\circ} \mathrm{C}\left(\mathrm{mm}^{2} \cdot \mathrm{s}^{-1}\right)$ & 4.20 & 4.21 & 4.25 \\
\hline Flashpoint ${ }^{*}\left({ }^{\circ} \mathrm{C}\right)$ & 157.5 & 153.5 & 154.5 \\
\hline Oxidation stability“* (h) & 9.2 & 9.7 & 10.0 \\
\hline
\end{tabular}

\section{Alcohols}

Glycerol can be catalytically converted into a complex mixture of lower alcohols using inorganic catalysts (supported $\mathrm{ZrO}_{2}^{49}$ and copper ${ }^{50}$ ) bacterium species such as Clostridium ${ }^{51,52,53,54}$, Klebsiella and Citrobacter $^{55,56}$, Enterobacter ${ }^{57}$, Escherichia coli ${ }^{15}$, and Saccharomyces cerevisiae ${ }^{58,59}$.

Table 9 - Fermentation of glycerol erol is dehydrated into 3-HPA, followed by hydrogenation of 1,3-propanediol by $\mathrm{NADH}_{2}$. On the other hand, glycerol is converted into glyceraldehyde-3-phosphate by DHA and into pyruvate which, in turn, is further metabolized to produce $\mathrm{NADH}_{2}$ and other subproducts (acetate, lactate, butyrate, ethanol, $\mathrm{H}_{2}$ and $\left.\mathrm{CO}_{2}\right)^{61}$. According to Barbirato et al. (1998), industrial production of 1,3-propanediol by means of Clostridium butyricum presented reasonable efficiency. The Table 9 shows the different types of bacterial species, media and growth conditions used for the production of 1,3-propanedi$\mathrm{ol}^{62,63}$. Most researchers use the pure glycerin. Rangaswamy, et al. (2010) used the crude glycerin, byproduct of biodiesel production from jatropha, with about 18$22 \%$ glycerol, $9 \%$ of free fatty acids, $29 \%$ soap, $10 \%$ moisture and volatile impurities, $14.5 \%$ methanol, $3 \%$ of methyl esters, $2.5 \%$ of sediment and $\mathrm{pH} 3.8^{63}$.

\begin{tabular}{|c|c|c|}
\hline Reference & Major product & Culture conditions \\
\hline Forsberg $(1987)^{51}$ & 1,3-propanediol & $\begin{array}{l}\text { Enrichment culture of Clostridium containing } 2 \% \text { pure } \\
\text { glycerol incubated at } 35^{\circ} \mathrm{C}, \mathrm{pH} 6.0 \text {, under stirring. }\end{array}$ \\
\hline Homann et al. $(1990)^{55}$ & 1,3-propanediol & $\begin{array}{l}\text { Enrichment culture of Klebsiella and Citrobacter } \\
\text { containing } 2 \% \text { pure glycerol incubated at } 32^{\circ} \mathrm{C}, \mathrm{pH} 7.0 \text {, } \\
\text { under stirring. }\end{array}$ \\
\hline Barbirato et al. $(1995)^{57}$ & 1,3-propanediol & $\begin{array}{l}\text { Enrichment culture of Enterobacter containing } 2 \% \text { pure } \\
\text { glycerol incubated at } 30^{\circ} \mathrm{C}, \mathrm{pH} 7.0 \text {, under stirring. }\end{array}$ \\
\hline Biebl $(2001)^{53}$ & Butanol & $\begin{array}{l}\text { Enrichment culture of Clostridium pasteurianum } \\
\text { containing } 2 \% \text { pure glycerol incubated at } 35^{\circ} \mathrm{C}, \mathrm{pH} 6.0 \text {, } \\
\text { under stirring. }\end{array}$ \\
\hline Tang et al. (2009) ${ }^{15}$ & 1,3-propanediol & $\begin{array}{l}\text { Enrichment culture of Escherichia coli containing } 2 \% \\
\text { pure glycerol incubated at } 30^{\circ} \mathrm{C}, \mathrm{pH} 6.8 \text {, under stirring. }\end{array}$ \\
\hline Yu et al. $(2010)^{50}$ & Ethanol & $\begin{array}{l}\text { Enrichment culture of Saccharomyces cerevisiae } \\
\text { containing } 2 \% \text { pure glycerol incubated at } 30^{\circ} \mathrm{C} \text {, neutral } \\
\mathrm{pH} \text {, under stiring. }\end{array}$ \\
\hline Rangaswamy et al. $(2010)^{83}$ & 1,3-propanediol & $\begin{array}{l}\text { Enrichment culture of Klebsiella pneumoniae containing } \\
2 \% \text { crude glycerol incubated at } 25^{\circ} \mathrm{C}, \mathrm{pH} 8.0 \text {, under } \\
\text { stirring. }\end{array}$ \\
\hline
\end{tabular}

Fermentation of glycerol by different microorganisms has been reported recently ${ }^{59}$.

Table 10 - Parameters of alcohol-gasoline blends

\begin{tabular}{lcc}
\hline \multicolumn{1}{c}{ Composition } & Energy (MJ/kg) & Motor octane number \\
\hline Glycerol/propanol/gasoline (6:60:34) & 33.25 & $>100$ \\
Propanol/propanediol/gasoline (40:40:20) & 28.63 & $>100$ \\
Ethanol/propanediol/gasoline (14:10:76) & 38.05 & 84 \\
\hline
\end{tabular}

Source: Fernando et al. (2007).

The application of glycerol as raw material for ethanol manufacture was evaluated recently, being feasible with recombinant S. cerevisiae strains. 1,3-Propanediol, one of the oldest fermentation products, was obtained from glycerol for the first time in $1881^{60}$. Glyc-
The use of alcohols derived from glycerol was studied by Fernando and colleagues (2007) in commercial gasoline. They evaluated the amount of energy and octane number of the mixtures (Table 10) ${ }^{64}$. The 14:10:76 ethanol/propanediol/gasoline mixture present- 
ed the highest energy value, but the other mixtures can also be used as fuel for spark ignition since their octane number is higher than 100 .

Anhydrous ethanol is added to gasoline for ignition engines in various countries, including Brazil. The use of ethanol as an additive of unleaded gasoline improves the performance of the engine and reduces significantly the carbon monoxide and hydrocarbon emissions (46.5\% and $24.3 \%$, respectively), though it increases the $\mathrm{CO}_{2}$ emissions in about $7.5 \%{ }^{65}$. Furthermore, addition of ethanol to diesel can decrease the particle matter formation, depending of the engine design. Nevertheless, considering the overall combustibility of such binary mixture, compere to pure diesel, some safety measures are required to its storage ${ }^{66}$. Ahmed et al. $(2001)^{67}$ has reported a reduction of $41 \%$ in particle matter and of 5\% in NOx emissions when ethanol-diesel mixtures were used in vehicles engines.

\section{Conclusion}

Oxygenated glycerol derivatives produced by etherification, acetalization, esterification and fermentation of glycerol represent a promising alternative energy sourcel, allowing the reuse of renewable residues, reduce the costs of residue treatment and increase the commercial coast of glycerol. However, most studies have used purified glycerol as raw material, hence crude glycerol leads to catalyst deactivation and lower chemical conversions.

\section{References}

1. Brasil. Presidência da República. Lei no 11.097, de 13 jan. 2005. Diário Oficial da União. Section 1. 14 jan. 2005.

2. Schuchardt, U.; Sercheli, R.; Vargas, R. M.; J. Braz. Chem. Soc. 1998, 9, 199.

3. Costa Neto, P. R., Rossi, L. F. S. Quim. Nova. 2000, 23, 531 .

4. Pinto, A. C.; Guarieiro, L. L. N.; Rezende, M. J. C.; Ribeiro, N. M.; Torres, E. A.; Lopes, W. A.; Pereira, P. A. de P.; Andrade, J. B. J. Braz. Chem. Soc. 2005, 16, 1313. 5. Johnson, D. T.; Taconi, K. A. EnViron. Prog. 2007, 26, 338.

6. Brown, R. http://www.icastusa.org/images/projects/ biodiesel/biodiesel_coproduct_markets.pdf; Biodiesel
Co-Product Markets in Wyoming, Wyoming Department of Agriculture, and International Center for Appropriate and Sustainable Technology, Lakewood, CO, 2007.

7. Holm-Nielsen, J. B.; Lomborg, C. J.; Oleskowicz-Popiel, P.; Esbensen, K. H. Biotechnol. Bioeng. 2008, 99, 302.

8. Lammers, P. J.; Kerr, B. J.; Weber, T. E.; Dozier, W. A.; Kidd, M. T.; Bregendahl, K.; Honeyman, M. S. J. Anim. Sci. 2008, 86, 602.

9. Cerrate, S.; Yan, F.; Wang, Z.; Coto, C.; Sacakli, P.;

Waldroupand, P. W. Int. J. Poult. Sci. 2006, 5, 1001.

10. Lammers, P. J.; Kerr, B. J.; Honeyman, M. S.; Stalder, K.; Dozier, W. A.; Weber, T. E.; Kidd, M. T.; Bregendahl, K. Poult. Sci. 2008, 87, 104.

11. Nascimento, M. da G.; Costa Neto, P. R.; Mazzuco, L. M.. Biotec. Ciênc. \& Desenv. 2001, 19, 28.

12. Melero, J. A.; Vicente, G.; Morales, G.; Paniagua, M.; Moreno, J. M.; Roldan, R.; Ezquerro, A.; Pérez. Appl. Catal. A: Gen., 2008, 346, 44.

13. Mota, C J. A.; Gonçalves, V. L. C.; Silva, C. X. A. da. Green Chem., 2009, 11, 38-41

14. Balaraju, M.; Nikhitha, P.; Jagadeeswaraiah, K.; Srilatha, K.; Sai Prasad, P. S.; Lingaiah, N. Fuel Process. Technol. 2010, 91, 249.

15. Tang, X.; Tan, Y.; Zhu, H.; Zhao, K.; Shen, W. Appl Environ Microbiol. 2009, 75, 1628.

16. Anp - Agência Nacional do Petróleo, Gás Natural e Biocombustíveis. Available at: http://www.anp.gov.br/ Accessed January 9, 2010.

17. Di Serio, M.; Ledda, M.; Cozzolino, M.; Minutillo, G.; Tesser, R. and Santacesaria, E. Ind. Eng. Chem. Res. 2006, 45, 3009.

18. Mahajan, S.; Konar, S. K.; Boocock, D. G. B.; J. Am. Oil Chem. Soc. 2007, 84, 189.

19. Day, P. Patent WO2008075003, 2008.

20. Faria, E. A.; Marques, J. S.; Dias, I. M. Andrade, R.

D. A.; Suareza, P. A. Z.; Prado, A. G. S. J. Braz. Chem. Soc., 2009, 20, 1732.

21. Doelling, G. L. Patent US2255916, 1941.

22. Queste, S.; Bauduin, P.; Touraud, D.; Kunz, W.; Aubry, J.-M. Green Chem. 2006, 8, 822.

23. Kesber, W. Patent WO2009147541, 2009.

24. Kesling, H. S.; Karas, L. K.; Liotta, F. J. Patent US005308365, 1994.

25. Theodore, E.; Edlund, K. R. Patent US1968033, 1934.

26. Karinen, R. S.; Krause, A. O. I. Appl. Catal. A. 2003, 306, 128.

27. Noureddini H, Daily WR, Hunt BA. Chem Biomol 
Eng Res. 1998, 13, 121.

28. Klepacova, K.; Mravec, D.; Bajus, M. Petrol. and Coal, 2003, 45, 54.

29. Klepacova, K.; Mravec, D.; Bajus, M. Chem. Pap. 2006, 60, 224.

30. Mota, C. J. A., Silva, C. X. A.; Gonçalves, V. L. C. Quim. Nova. 2009, 32, 639.

31. Hunt, B. A. Chem. Biomol. Eng. Res. 1998, 13, 121. 32. Karas, L. J.; Kesling, H. S.; Liotta, F. J.; Nandi, M. K. In: ACS, Div. of Fuel Chemistry. 1994, 39, 316.

33. Arredondo, V. M.; Back, D. J.; Corrigan, P. J.; Kreuzer, D. P.; Cearley, A. C. Patent WO2007/113776, 2007. 34. Mota, C. J. A.; Silva, C. R. B. da; Gonçalves, V. L. C.; Lachter, E. R. J. Braz. Chem. Soc. 2009, 20, 201. 35. Pariente, S.; Tanchoux, N.; Fajula, F. Green Chem. 2009, 11, 1256.

36. Delfort, B.; Durand, I.; Jaecker, A. Lacome, T.; Montagne, X. Paille, F. Patent US2003163949, 2003.

37. Nord, K. E.; Haupt, D. Environ. Scie. \& Techn. 2005, 39, 6260 .

38. Mota, C. J. A.; Silva, C. X. A. da; Rosenbach Jr., N.; Costa, J.; Silva, F. da. Energy Fuels. 2010, 24, 2733.

39. Bruchmann, B.; Karl, H.; Helmut, G.; Michael, H. Patent US5917059, 1999.

40. Garcia, E.; Laca, M.; Pérez, E.; Garrido, A.; Peinado, J. Energy \& Fuels. 2008, 22.

41. Piantadosi, C.; Anderson, C. E.; Brecht, E. A.; Yarbro, C. L. J. Am. Chem. Soc., 1958, 80, 6613.

42. Sato, S.; Shigueru Araujo, A.; Miyano, M. Patente US 0207927. 2008.

43. Galan, M.-I.; Bonet, J.; Sire, R.; Reneaume, J.-M.;

Plesu, A. E. Bioresour. Technol. 2009, 100, 3775.

44. Ogawa, T. Moriwaki, N. Fujii, R.; Tanaka, K.; Mori, E.; Saitou, M.; Yoshizawa, H.; Sakaguchi, H. Kitasato Arch. Exp. Med. 1992, 65, 33.

45. Gelosa, D. Ind. Eng. Chem. Res. 2003, 42, 6536.

46. Mota, C. J. A.; Gonçalves, V. L. C.; Pinto, B. P.; Silva, J. C. Catal. Today. 2008, 133, 673.

47. Delgado, P. J. European Patent EP1331260, 2003.

48. Ferreira, P.; Fonseca, I. M.; Ramos, A. M.; Vital, J.; Castanheiro, J. E. Catal. Commun. 2009, 10, 481.

49. Kurosaka, T.; Maruyama, H.; Naribayashi, I.; Sasaki,

Y.. Catal. Commun. 2008, 9, 1360.

50. Guo, L.; Zhou, J.; Mao, J.; Guo, X., Zhang, S. Appl.

Catal. A: Gen. 2009, 367, 93.

51. Forsberg, Cecil W. Appl. Environ. Microbiol. 1987,

53,639 .

52. Himmi, E. H.; Bories, A.; Barbirato, F. Bioresour.

Technol. 1999, 67, 123.

53. Biebl H. J. Ind. Microbiol. Biotechnol. 2001, 27, 18.
54. Nakamura, C. E.; Whited, G. M. Curr Opin Biotechnol. 2003, 14, 454 .

55. Homann, T.; Tag, C.; Biebl, H.; Deckwer, W.D.;

Schink, B. Appl. Microbiol. Biotechnol. 1990, 33, 121. 56. Menzel, K.; Zeng, A.-P.; Deckwer, W.-D. Enzyme Microb. Technol. 1997, 20, 82.

57. Barbirato, F.; Camarasa-Claret, C.; Grivet, J. P.; Bories, A. Appl. Microbiol. Biotechnol. 1995, 43, 786. 58. Yazdani, S. S.; Gonzalez, R. Metab. Eng. 2008, 10, 340.

59. Yu, K. O.; Kim, S. W.; Han, S. O. Biores. Tech. 2010, $101,4157$.

60. Contiero, J.; Silva, G. da P.; Mack, M. Biotechn. Adv., 2009, 27, 30.

61. Saxena, R. K.; Anand, P.; Saran, S.; Isar, J. Biotech. Adv. 2009, 27, 895.

62. Barbirato, F.; Himmi, E. H.; Conte T.; Bories A. Indust. Crops Prod. 1998; 7, 281.

63. Rangaswamy, V.; Kannabiran, M.; Rangaswamy, V. New Biotech. 2010, 00, 00.

64. Fernando, S.; Adhikari, S.; Kota, K.; Bandi, R.. Fuel, 2007, 86, 2806.

65. Al-Hasan, M. Ener. Conv. $n$ and Manag. 2003, 44, 1547.

66. Hansen, A. C.; Zhang, Q.; Lyne, P. W. L. Bioresour. Technol. 2005, 96, 277.

67. Ahmed I. SAE. 2001, technical paper 2001-01-2475.

68. Di Serio M; Casale L.; Tesser, R., and Santacesaria,

E.. Energy Fuels, 2010, XXXX, 000.

69. Patzer, R. Agricultural Utilization Research Institute. Marshall, MN, USA, 2007. Available at: http:// www.auri.org/research/Glycerin\%20Report\%20Final. pdf. Accessed July 22, /2010.

70. Demirbas A. Energy Sour Part A Recov Util Environ Effects. 2009, 31, 1770.

71. Frusteri, F.; Arena, F.; Bonura, G.; Cannilla, C.;

Spadaro, L.; Di Blasi, O. Appl. Catal. A: Gen. 2009, 367, 77.

72. Rahmat, N.; Abdullah, A. Z.; Mohamed, A. R. Renew Sustain Energy Rev. 2010, 14, 987. 